\title{
Combination of Solanum nigrum L. Herb Ethanolic Extract and Doxorubicin Performs Synergism on T47D Breast Cancer Cells
}

\author{
Anindyajati, Sarmoko, Dyaningtyas D. P. Putri, Adam Hermawan, and Edy Meiyanto* \\ Cancer Chemoprevention Research Center, Faculty of Pharmacy, Universitas Gadjah Mada, Yogyakarta \\ http://ccrc.farmasi.ugm.ac.id
}

\begin{abstract}
Leunca (Solanum nigrum L.) has been proven to possess anticancer activity on some type of cancer cells. In vitro study of solamargine found in the herb showed cytotoxic effect against several breast cancer cell lines, such as T47D and MDA-MB-3I. Hence, further study on its potential as a co-chemotherapeutic agent needs to be conducted, in order to overcome resistance problem commonly found in cancer chemotherapy. This study aimed to examine the cytotoxic activity of leunca herb ethanolic extract (LEE) alone and its combination with doxorubicin. Single and combinational treatment of LEE and doxorubicin on T47D breast cancer cells were done, and their viability representing cytotoxicity were analyzed by using MTT assay to determine the $I_{50}$ value and combination index $(\mathrm{Cl})$ to evaluate the combinational effect. Twenty four hours-treatment of LEE alone gave cytotoxicity activity showing a dose-dependent manner with the $\mathrm{IC}_{50}$ of $47 \mu \mathrm{g} / \mathrm{ml}$, while combinational treatment showed that $4 \mu \mathrm{g} / \mathrm{ml}$ LEE was found to be synergist with $4 \mathrm{nM}$ doxorubicin on T47D cells, with the optimum $\mathrm{Cl}$ value of 0.59 . This result shows that Solanum nigrum $\mathrm{L}$. is potential to be proposed as doxorubicin co-chemotherapeutic agent against breast cancer. Further study on its molecular mechanism needs to be conducted.
\end{abstract}

Keywords: Solanum nigrum, doxorubicin, synergist, breast cancer

\section{INTRODUCTION}

Doxorubicin, a chemotherapy agent that is applicable for the treatment of several cancer types, is widely used in the treatment of breast cancer. Medical report by Rumah Sakit Kanker Dharmais stated that in 2007 breast cancer shows the highest incidence compared to another cancer types (Anonym, 2009). The main problems being faced in the application of chemotherapeutic agent are its toxicity towards normal tissues, suppression of the immune system (Wattanapitayakul et al., 2005), and occurrence of resistance (Mechetner et al., 1998). One promising approach to solve this problem is the application of co-chemotherapeutic agent in cancer therapy.

Co-chemotherapy may increase chemotherapeutic agents' efficacy, allowing the use of lower dosage of chemotherapeutic agent, resulting in the decrease of toxicity on normal tissues. Potent agent which can be use as co- chemotherapeutic agent together with doxorubicin are phytochemical substances, rendering to the fact that there are huge number of substances found in plants that are potential against cancer (Gibbs, 2000), such as solanine, solasodine, and solamargine found in leunca (Solanum nigrum L.) herb (Everist, 1974; Weller and Phipps, 1979). Those steroidal glycosides have been proven to possess anticancer activity (Saijo et al., 1982). Solamargine as the main constituent being responsible for leunca's anticancer activity $(\mathrm{Hu}$, 1999) performed cytotoxic activity on several cancer cell lines, including T47D and MDA-MB231 breast cancer cells. Besides, it also induces programmed cell death, apoptosis, through mitochondrial pathway (Liang, 2008). Therefore, further study on its potential as cochemotherapeutic agent needs to be conducted.

*Corresponding author e-mail : meiyan_e@ugm.ac.id 
This study aimed to observe the effect of leunca's ethanolic extract (LEE) application to the cytotoxicity performed by doxorubicin, analyzed by using MTT assay. Combinatorial treatment of doxorubicin and LEE were applied in order to increase the cytotoxicity of doxorubicin on T47D cells, allowing the use of lower dose of the chemotherapeutic agent giving less toxicity on normal tissues.

\section{METHODS}

\section{Sample preparation}

Dried powder of leunca herbs were purchased from Balai Besar Penelitian dan Pengembangan Tanaman Obat dan Obat Tradisional (B2P2TOOT), Indonesia. Dried powder was then extracted by maceration for 5 days with $70 \%$ ethanol. Collected filtrate was concentrated using rotary evaporator (Heidolph WB2000), then dissolved in Dimethyl Sulfoxide (DMSO) (Sigma). Both Doxorubicin $5 \mathrm{mg} / \mathrm{ml}$ and extract solution were diluted in DMEM cell culture medium before being applied.

\section{Chemicals}

Dulbecco's Modified Eagle Medium (DMEM) powder (Gibco), Fetal Bovine Serum (FBS) $10 \% \mathrm{v} / \mathrm{v}$ (Gibco), and Penicillin-Streptomycin $10,000 \quad$ units/ml penicillin-10,000 $\mu \mathrm{g} / \mathrm{ml}$ streptomycin (Gibco) were used for cell culture medium. Cells were prepared using Tripsin EDTA $25 \%$ (Gibco). For cytotoxicity assay, Sodium Dodecyl Sulphate (SDS) $10 \% \%$ v (Merck) dissolved in $\mathrm{HCl} 0.1 \mathrm{~N}$ (Merck) as stopper reagent, Phosphate Buffer Saline (PBS) pH 7.4 containing KCl (HPLC grade, Sigma), $\mathrm{NaCl}$ (HPLC grade, Sigma), $\mathrm{Na}_{2} \mathrm{HPO}_{4}$ (HPLC grade), and $\mathrm{KH}_{2} \mathrm{PO}_{4}$ (HPLC grade, Sigma) dissolved in aquadest as washing reagent, and 3-[4,5-dimethyl thiazole-2-yl(-2,5diphenyltetrazoliumbromide)] (MTT) dissolved in PBS as MTT reagent were used.

\section{T47D cells}

T47D cells being used were from the collection of Cancer Chemoprevention Research Center (CCRC), Universitas Gadjah Mada. The cell line was a gift from Prof. Kawaichi, Nara Institute of Science and Technology (NAIST), Japan.

\section{Cytotoxicity and combinational assay}

MTT cytotoxicity assay was used to examine the effect of LEE alone and in combination with doxorubicin on T47D cells. T47D cells was distributed to 96 -well plate with the density of $5 \times 10^{3}$ cells/well and incubated in $37^{\circ} \mathrm{C}$ with $5 \% \quad \mathrm{CO}_{2}$ for 24 hours. For the cytotoxicity assay of LEE on T47D cells alone, LEE was applied with the concentration of $1,10,50,100$, 250,500 , and $750 \mu \mathrm{g} / \mathrm{ml}$ to find $\mathrm{IC}_{50}$. In combinational assay, concentration of about $\frac{1}{2}, \frac{3}{8}, \frac{1}{4}$ and $\frac{1}{8} \mathrm{IC}_{50}$ acquired were used for both LEE and doxorubicin, giving the concentration of $18,12,6$, and $4 \mu \mathrm{g} / \mathrm{ml}$ for LEE and 6, 4, 2, and $1.5 \mathrm{nM}$ for doxorubicin. After 24 hours incubation, MTT reagent was applied, followed by 4 hours incubation. $\mathrm{SDS} 10 \% \mathrm{v}$ in $\mathrm{HCl} 0.1 \mathrm{~N}$ as stopper reagent was then applied. Plate was then kept with protection from light overnight, continued with absorbance determination $(\lambda 595 \mathrm{~nm})$ using ELISA reader (Bio-Rad).

\section{Analysis}

Single Cytotoxicity assay

Linear regression between log concentration and $\%$ cell viability giving the equation $\mathrm{y}=\mathrm{Bx}+\mathrm{A}$ were used to calculate $\mathrm{IC}_{50}$ value, that is the concentration inhibiting $50 \%$ cell proliferation.

Combinational Cytotoxicity Assay

Combinational treatment was evaluated by calculating Combination Index (CI) value (Reynolds and Maurer, 2005), which has the formula as follows.

$$
\mathrm{CI}=\frac{\mathrm{D} 1}{\mathrm{Dx} 1}+\frac{\mathrm{D} 2}{\mathrm{Dx} 2}
$$

D1 and D2 represent concentrations used in combinational treatment, while Dx1 and Dx2 are single treatment concentration giving the same response as D1 and D2, respectively. CI value acquired will allow the evaluation of LEE's potency in combinatorial treatment with doxorubicin on T47D cell lines. Interpretation was done based on the classification listed in table 1 . 
Table I. Interpretation of $\mathrm{Cl}$ value representing potency of combinational application

\begin{tabular}{cccc}
\hline Cl value & Interpretation & $\mathbf{C l}$ & Interpretation \\
\hline$<0.1$ & Very strongly synergist & $0.9-I . I$ & Closely additive \\
$0.1-0.3$ & Strongly synergist & $1 . I-I .45$ & Middle antagonist \\
$0.3-0.7$ & Synergist & $1.45-3.3$ & Antagonist \\
$0.7-0.9$ & Middle synergist & $>3.3$ & Strongly antagonist \\
\hline
\end{tabular}

\section{RESULTS}

Treatment of LEE on T47D cells gave the value of cell viability shown in table 2 . Increasing LEE concentration resulting in the increase of cytotoxicity. Linear regression of LEE concentration against \% cell viability (figure 1) gave the $\mathrm{IC}_{50}$ value of $47 \mu \mathrm{g} / \mathrm{ml}$. Doxorubicin's $\mathrm{IC}_{50}$ on T47D cells is $15 \mathrm{nM}$ (Junedi, 2010). Observation of cell morphology after treatment was also done, shown in figure 2. Increasing concentration of LEE was followed by the increasing number of dead cells, quantitatively. Both qualitative and quantitative data prove that single treatment of LEE on T47D cells showed a dose-dependent manner.

Combinational treatment of LEE and doxorubicin on T47D cells gave the CI value shown in table 3 , and being plotted in diagram (figure 3). It shows that 4 concentration combinations, that are doxorubicin $1 /{ }_{8} \mathrm{IC}_{50}-$ LEE $1 / 2 \quad \mathrm{IC}_{50}$, doxorubicin $3 / 8 \mathrm{IC}_{50}-\mathrm{LEE}^{1} / \mathrm{IC}_{50}$, doxorubicin $3 /{ }_{8} \mathrm{IC}_{50}-$ LEE $1 / 4$ $\mathrm{IC}_{50}$, and doxorubicin $3 /{ }_{8} \mathrm{IC}_{50}-\mathrm{LEE} 1 / 2 \quad \mathrm{IC}_{50}$, combination of shows synergicity on T47D cells, with CI values less than 0.9. Cell morphology after treatment was observed (figure 4). Treatment of LEE and doxorubicin alone led to cells' morphological change pointed by black arrows, respectively (figure 4(b) and 4(c)). Combination of them caused more changes compared to single treated cells (figure 4(d)). While control cells showed no change in cells' morphology representing cells' death (figure 4(a)). Hence, synergism of combinational treatment was observed.

Table II. \% cells viability in single treatment of LEE on T47D cells

\begin{tabular}{cc}
\hline LEE concentration $(\boldsymbol{\mu g} / \mathbf{m l})$ & \% cell viability \\
\hline 750 & 2.33 \\
500 & 4.53 \\
250 & 9.91 \\
100 & 43.94 \\
50 & 73.81 \\
10 & 76.01 \\
1 & 102.57 \\
\hline
\end{tabular}

\section{DISCUSSION}

This study had observed that treatment of LEE on T47D breast cancer cells could inhibit cells' growth with a dose-dependent manner. Higher dose of LEE brought less cell viability, showing higher toxicity. $\mathrm{LEE} \mathrm{IC}_{50}$ value on $\mathrm{T} 47 \mathrm{D}$ cells of $47 \mu \mathrm{g} / \mathrm{ml}$ was acquired. It represents LEE's efficacy as a single cytotoxic agent. According to Ueda, 2000, $\mathrm{IC}_{50}$ value less than $100 \mu \mathrm{g} / \mathrm{ml}$ shows that related agent has a potent cytotoxicity. The mechanism of cytotoxic activity of solanine and solamargine, two steroidal glycosides found in leunca herb, had been previously studied. However, its specific molecular target has not been discovered yet.

Previous study proved that solamargine and solanine could suppress Bcl-2 protein expression (Liu et al., 2004; Ji et al., 2008). Bcl-2 functioned as antiapoptotic protein that inhibit cells' death 
through apoptosis, thus its suppression may trigger cancer cells' death (Pandanilam, 2003). Bcl-2 suppression plays a role in apopotosis induction by triggering mitochondrial release of cytochrome $\mathrm{c}$ which later activates the caspase cascade. Hence, one possible mechanism of LEE's cytotoxic activity is by apoptosis induction. Apoptosis may occur involving the role of several types of proapoptotic proteins, such as Bad, Bax, and Bak (Ricci and Zong, 2006). Further study needs to be conducted to observe whether or not LEE triggers apoptosis and also its ability to affect the expression of both proapoptotic and antiapoptotic proteins other than Bcl-2 on T47D cells.

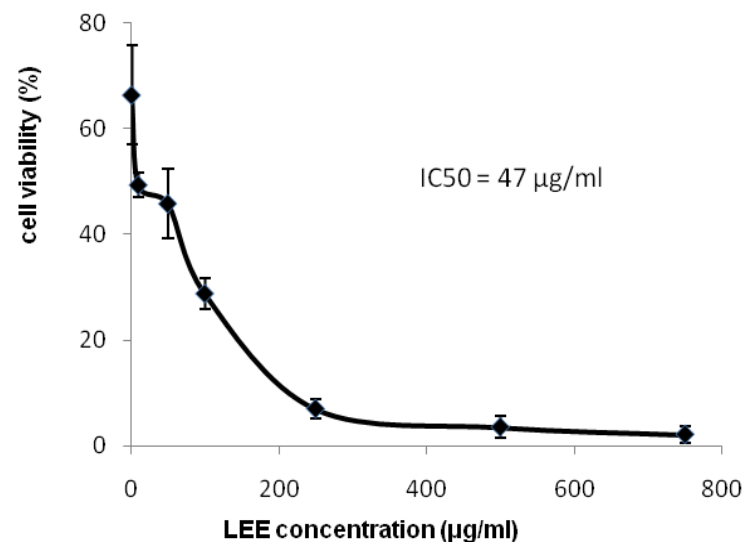

Figure I. Curve of log LEE concentration against \% cell viability on T47D cells, showing a dose-dependent manner. Linear regression gave the equation $y=-37.56 x$ I I $2.7 I$, giving IC 50 value of $47 \mu \mathrm{g} / \mathrm{mI}$.

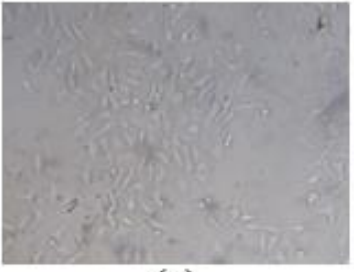

(a)

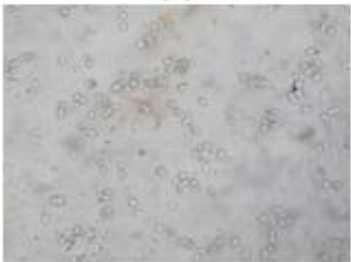

(d)

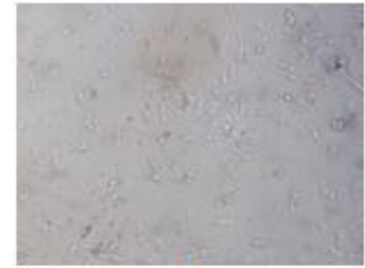

(b)

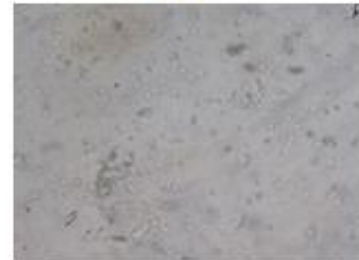

(e)

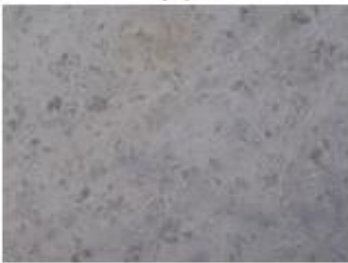

(g)

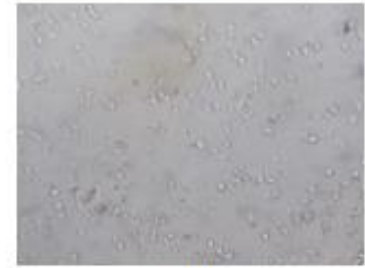

(c)

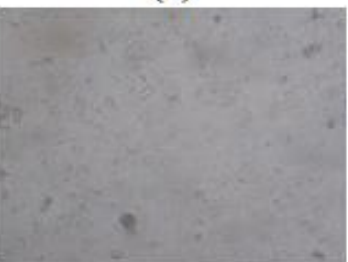

(f)

Figure 2. T47D cells' morphology after 24 hours LEE treatment;(a) I $\mu \mathrm{g} / \mathrm{ml}$; (b) $10 \mu \mathrm{g} / \mathrm{ml}$; (c) $50 \mu g / \mathrm{ml}$; (d) $100 \mu \mathrm{g} / \mathrm{ml} ;$ (e) $250 \mu \mathrm{g} / \mathrm{ml}$;(f) $500 \mu \mathrm{g} / \mathrm{ml} ;$ (g) $750 \mu \mathrm{g} / \mathrm{ml}$. Higher concentration of LEE caused more change in cells' morphology (round cells being unattached to the well). This phenomenon represents a dose-dependent manner. 
Table III. CI values of combinational treatment of LEE and doxorubicin on T47D cells

\begin{tabular}{ccccc}
\hline \multirow{2}{*}{ LEE concentration $(\mu \mathrm{g} / \mathrm{ml})$} & \multicolumn{4}{c}{ Doxorubicin $(\mathrm{nM})$} \\
\cline { 2 - 5 } & 1.5 & 2 & 4 & 6 \\
\hline 4 & 1.54 & 1.41 & $\mathbf{0 . 5 9}$ & 1.83 \\
6 & 2.92 & 2.04 & $\mathbf{0 . 8 1}$ & 2.43 \\
12 & 0.97 & 2.05 & 1.27 & 1.86 \\
18 & $\mathbf{0 . 7 9}$ & 1.14 & $\mathbf{0 . 7 5}$ & 1.31 \\
\hline
\end{tabular}

Bold numbers shows combination resulting in $\mathrm{Cl}$ value below 0.9 , which are synergist.

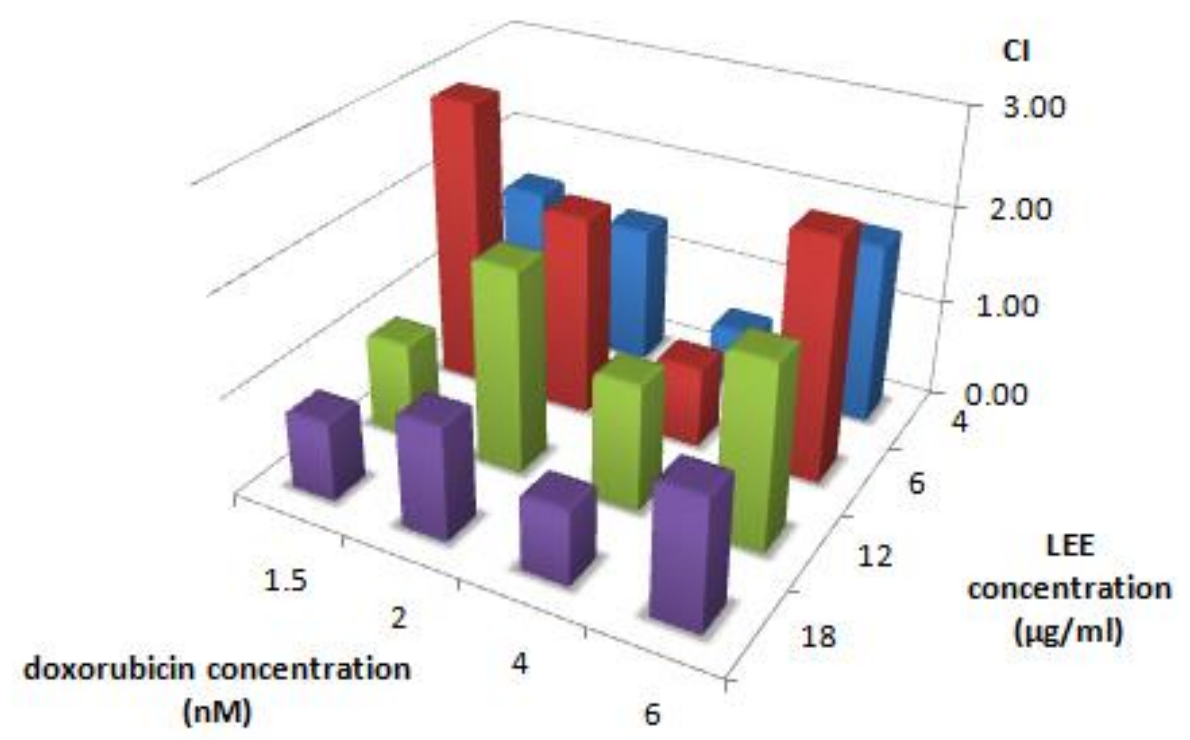

Figure 3. Diagram of combinational effect of LEE and doxorubicin against $\mathrm{Cl}$ value. $\mathrm{Cl}$ value below 0.9 shows sinergicity. 


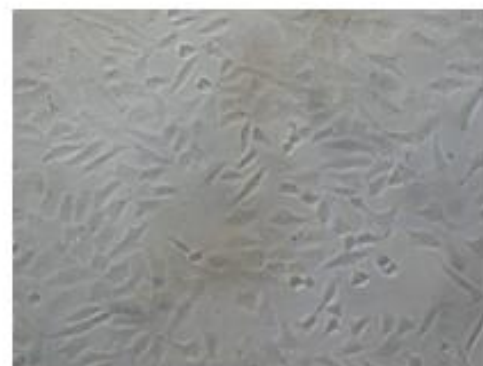

(a)

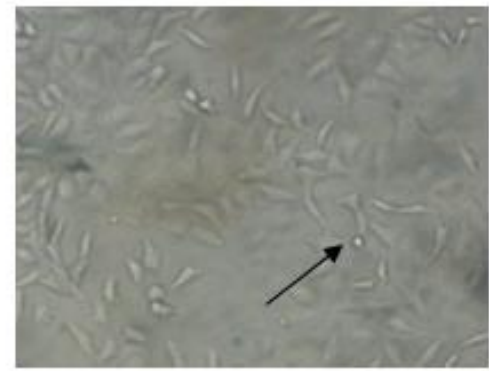

(c)

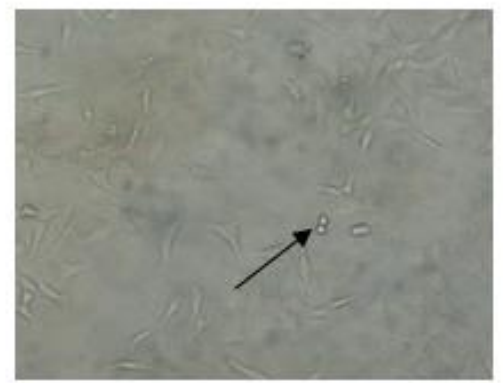

(b)

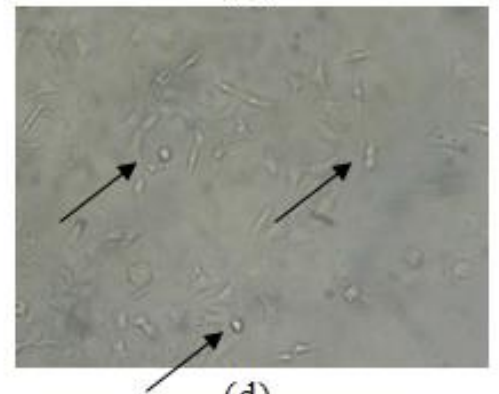

(d)

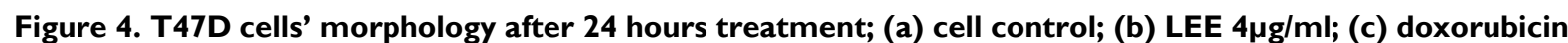
$4 \mathrm{nM}$; (d) doxorubicin $4 \mathrm{nM}$ in combination with LEE $4 \mu \mathrm{g} / \mathrm{ml}$. Treatment of LEE and doxorubicin alone brought cells to death, shown by change in cells' morphology pointed by black arrows, respectively (figure (b) and (c)). Combination of them caused more cells' death compared to single treated cells (figure (d)), showing sinergicity. While control cells showed no change in cells' morphology representing cells' death (figure (a)).

The efficacy of combination between LEE and doxorubicin on T47D cells were analyzed to determine their combinational effect, whether they are synergist, additive, or antagonistic. It allows us to know LEE's ability to increase chemotherapeutics agents' effectiveness that is commonly used in breast cancer therapy. Result shows that four combinational doses of doxorubicin and LEE performs synergism on their cytotoxicity towards T47D cells, meaning that doxorubicin's theraputical dose may be lessen by the application of LEE as a cochemotherapeutic agent, giving equal effectiveness in inhibiting cancer cells' growth.

Synergism observed possibly occur because of the ability of LEE to strengthen doxorubicin's cytotoxic effect. In this case, doxorubicin is cytotoxic towards cells by inhibiting topoisomerase II activity (Potter et al., 2002), and was strengthened with the cytotoxic activity of solanine and solamargine, possibly by triggering apoptosis or by inducing cell cycle arrest. Another study is required to know the exact mechanism of synergism between doxorubicin and LEE. Further study on LEE apoptosis induction and its effect on related proteins expression need to be conducted in order to know more about its cytotoxic molecular mechanism.

\section{CONCLUSION}

From the study, it can be concluded that Solanum nigrum herbs' ethanolic extract is cytotoxic and is able to increase doxorubicin's cytotoxicity on T47D breast cancer cells.

\section{REFERENCES}

Anonym, 2009, Rumah Sakit Kanker Dharmais' Medical Report; Statistik Kanker: 10 Besar Kanker Tersering RSKD Rawat Jalan (Kasus Baru) tahun 2007, available in

http://www.dharmais.co.id/index.php/cancestatistic.html, accessed on March 2010.

Everist, S.L. 1974, Poisonous Plants of Australia, Angus and Robertson, Sydney.

Gibbs, J.B., 2000, Anticancer Drug Targets: Growth Factor and Growth Factor Signaling, J. Clin. Inves., I05(I), 9-I3. 
Hu, K., Kobayashi, H., Dong, A., Jing, Y., Iwasaki, S. and Yao, X., 1999, Antineoplastic Agents III: Steroidal Glycosides from Solanum nigrum, Planta Med., 65(I), 35-38.

Ji, Y.B., Gao, S.Y., Ji, C.F. and Zou, X., 2008, Induction of Apoptosis in HepG2 Cells by Solanine and $\mathrm{Bcl}-2$ protein, J. Ethnopharmacol., I I 5(2), 194-202.

Junedi, Sendy, 2010, Peningkatan Aktivitas Sitotoksik Doxorubicin oleh Naringenin pada Sel Kanker Payudara T47D melalui Modulasi Siklus Sel dan Pemacuan Apoptosis, Thesis, Program Pascasarjana Program Studi Ilmu Farmasi Universitas Gadjah Mada, Yogyakarta.

Liang, C.H., Shiu, L.Y., Chang, L.C., Sheu, H.M., Tsai, E.M. and Kuo, K.W., 2008, Solamargine Enhances HER2 Expression and Increases the Susceptibility of Human Lung Cancer $\mathrm{H} 66 \mathrm{I}$ and H69 Cells to Trastuzumab and Epirubicin, Chem Res. Toxicol., 2 I (2), 393-399.

Liu, L.F., Liang, C.H., Shiu, L.Y., Lin, W.L., Lin, C.C. and Kuo, K.W., 2004, Action of Solamargine on Human Lung Cancer Cells-Enhancement of The Susceptibility of Cancer Cells to TNFs, FEBS Lett., 577(I-2), 67-74.

Mechetner, E., Kyshtoobayeva, A., Zonis, S., Kim, H., Stroup, R., Garcia, R., Parker, R.J. and Fruehauf, J.P., 1998, Levels of Multidrug
Resistance (MDRI) P-Glycoprotein Expression by Human Breast Cancer Correlate with in vitro Resistance to Taxol and Doxorubicin, Clin. Cancer Res., 4, 389-398.

Pandanilam, B.J., 2003, Cell Death Induced by Acute Renal Injury: A Perspective on the Contributions of Apoptosis and Necrosis, Am. J. Physiol. Renal Physiol., 284, 608-627.

Reynolds, C.P. and Maurer B.J., 2005, Evaluating Response to Antineoplastic Drug Combinations in Tissue Culture Models, Methods in Molecular Medicine, I I 0, I73183.

Saijo, R., Murakami K., Nohara T., Tomimatsu T., Sato A. and Matsuoka K., 1982, Studies on the Constituents of Solanum Plants II: Constituents of the Immature Fruits of Solanum nigrum, Yakugaku Zasshi, I02, 300-305.

Wattanapitayakul, S.K., Chularojmontri L., Herunsalee A., Charuchongkolwongse S., Niumsakul S. and Bauer J.A., 2005, Screening of Antioxidants from Medicinal Plants for Cardioprotective Effect against Doxorubicin Toxicity, Basic and Clin. Pharmacol. and Toxicol., 96(I), 80-87.

Weller, R.F. and Phipps, R.H., 1979, A Review of The Black Nightshade (Solanum nigrum L.), Protection Ecology, I, I 2 I-I 39. 